\author{
KRZYSZTOF W. BARAN \\ ORCID: 0000-0001-5165-8265 \\ Uniwersytet Jagielloński \\ IZABELA FLORCZAK \\ ORCID: 0000-0003-3167-3382 \\ Uniwersytet Łódzki
}

\title{
KOGNICJA SĄDÓW W SPRAWACH ZATRUDNIENIA OSÓB WYKONUJĄCYCH PRACE ZAROBKOWA NA INNEJ PODSTAWIE NIŻ STOSUNEK PRACY
}

\begin{abstract}
Abstrakt: Aby móc w pełni i świadomie realizować prawo do sądu, podmiot, który chce z niego skorzystać, powinien mieć jasność co do ścieżki drogi sądowej. Jednym z fundamentów realizacji prawa do sądu jest możliwość ustalenia kognicji sądu. Aktualnie obowiązujący stan prawny pozostawia liczne wątpliwości co do zakresu kognicji sądu w sprawach zatrudnienia osób wykonujących pracę zarobkową na innej podstawie niż stosunek pracy. Jest to szczególnie widoczne w ramach zatrudnienia administracyjnoprawnego oraz $\mathrm{w}$ ramach świadczenia pracy na podstawie umów uregulowanych w kodeksie cywilnym. Niespójność systemowa czyni wątpliwym pełną realizację przez polski system prawa gwarancji prawa do sądu, wymagając określenia zakresu kognicji sądów na wskazanych płaszczyznach.
\end{abstract}

Słowa kluczowe: kognicja sądów, sprawy zatrudnienia, osoby wykonujące pracę zarobkową, niepracownicy

\section{ZAGADNIENIA WPROWADZAJĄCE}

Jedną z fundamentalnych gwarancji wolności obywatelskich w państwie demokratycznym jest prawo do sądów. Powszechne uznanie tego prawa przez społeczeństwa cywilizowane znalazło odbicie $\mathrm{w}$ wielu aktach prawa międzynarodowego, w tym między innymi w Międzynarodowym Pakcie Praw Obywatelskich i Politycznych ${ }^{1}$ wraz z protokołami fakultatywnymi oraz europejskiej Konwencji

1 Międzynarodowy Pakt Praw Obywatelskich i Politycznych otwarty do podpisu w Nowym Jorku dnia 19 grudnia 1966 roku (Dz.U. z 1977 r. Nr 38, poz. 167). 
o ochronie praw człowieka i podstawowych wolności². W systemie ustawodawstwa polskiego prawo do sądu zostało zadekretowane w normach rangi konstytucyjnej, a konkretnie w art. 45 i 77 Konstytucji $^{3}$. Zgodnie z postanowieniami art. 45 ust. 1 Konstytucji RP każdy ma prawo do sprawiedliwego i jawnego rozpatrzenia sprawy bez nieuzasadnionej zwłoki przez właściwy niezależny, bezstronny i niezawisły sąd. Z kolei art. 77 ust. 2 Konstytucji RP formułuje dyrektywę, że ustawa nie może nikomu zamykać drogi sądowej dochodzenia naruszonych wolności lub praw. Przyjęta w cytowanych normach regulacja ma charakter uniwersalny, gdyż odnosi się zarówno do aspektu procesowo-organizacyjnego (art. 45 ust. 1), jak i funkcjonalno-kompetencyjnego (art. 77 ust. 3). W tym kontekście jest oczywiste, że droga sądowa pozostaje otwarta dla ochrony wolności i praw naruszonych W związku z zatrudnieniem. W ramach tematyki niniejszego opracowania istotne jest zatem rozstrzygnięcie nie „czy”, ale ,jak” (w ramach kognicji których sądów) realizowane jest prawo do sądu w sprawach zatrudnienia osób wykonujących pracę zarobkową na innej podstawie niż stosunek pracy. Na potrzeby niniejszego opracowania pod pojęciem kognicji sądu rozumiemy zakres kompetencji orzeczniczej.

Podejmując problematykę proceduralną w sprawach zatrudnienia w zakreślonych dla niniejszego opracowania ramach, przede wszystkim należy zdefiniować termin „sprawa zatrudnienia”, ponieważ nie ma on definicji legalnej. Punktem wyjścia będzie stwierdzenie, że termin ten może być rozmaicie pojmowany. W wąskim ujęciu (sensu stricto) może odnosić się do spraw określonych w art. $476 \S 1$ pkt 2 kodeksu postępowania cywilnego ${ }^{4}$. W ujęciu szerokim (sensu largo) pojęcie sprawy zatrudnienia może obejmować wszystkie sprawy dochodzone na drodze sądowej przez tak zwanych niepracowników. Wreszcie, w najszerszym ujęciu (sensu largissimo), może obejmować wszystkie sprawy z zakresu prawa pracy w rozumieniu art. $476 \S 1$ k.p.c. oraz wszystkie inne kategorie spraw z zakresu prawa cywilnego i administracyjnego dochodzone przez „niepracowników” od podmiotów zatrudniających. Ze względu na temat tego opracowania swoją uwagę skoncentrujemy na osobach wykonujących pracę zarobkową na podstawie innej niż stosunek pracy.

Analizę problematyki kognicji sądów podjętą w tym opracowaniu należy również poprzedzić zdefiniowaniem pojęcia „osoby wykonującej pracę zarobkową na podstawie innej niż stosunek pracy”. Punktem wyjścia będzie stwierdzenie, że ta kategoria osób nie jest zdefiniowana kategoriami prawa o charakterze proceduralnym. $\mathrm{Z}$ tego też względu a completudine należy odwołać się do terminologii zbiorowego prawa zatrudnienia.

${ }^{2}$ Konwencja o ochronie praw człowieka i podstawowych wolności sporządzona w Rzymie dnia 4 listopada 1950 roku (Dz.U. z 1993 r. Nr 1, poz. 281).

3 Konstytucja Rzeczypospolitej Polskiej z dnia 2 kwietnia 1997 roku (Dz.U. z 1997 r. Nr 78, poz. 483 ze zm., dalej: Konstytucja RP). Por. bliżej K. Baran, [w:] K. Baran, D. Książek, M. Wujczyk, Procesowe prawo pracy, Warszawa 2013, s. $70 \mathrm{n}$.

${ }^{4}$ Ustawa z dnia 17 listopada 1964 roku — Kodeks postępowania cywilnego (tekst jedn. Dz.U. z 2020 r. poz. 1575 ze zm., dalej: k.p.c.). 
Pojęciem „osoby świadczącej pracę za wynagrodzeniem na innej podstawie niż stosunek pracy" posługuje się art. $1^{1}$ pkt 1 ustawy o związkach zawodowych ${ }^{5}$. W jego zakresie podmiotowym mieszczą się osoby świadczące pracę na podstawach cywilnoprawnych, w tym także samozatrudnione oraz funkcjonariusze służb mundurowych zatrudnieni na podstawie mianowania w ramach stosunku administracyjnoprawnego. Na tle analizowanej problematyki w pierwszej kolejności należy, w ujęciu ogólnoteoretycznym, przedstawić relację logiczną między tą kategorią podmiotową a proceduralnym pojęciem pracownika $\mathrm{z}$ art. $476 \S 5$ k.p.c. W naszej ocenie zachodzi między nimi stosunek krzyżowania w formule podprzeciwieństwa, przy założeniu, że zakres podmiotowy jest ujęty w sposób kompleksowy, co można zaprezentować w formie graficznej jak poniżej.

A

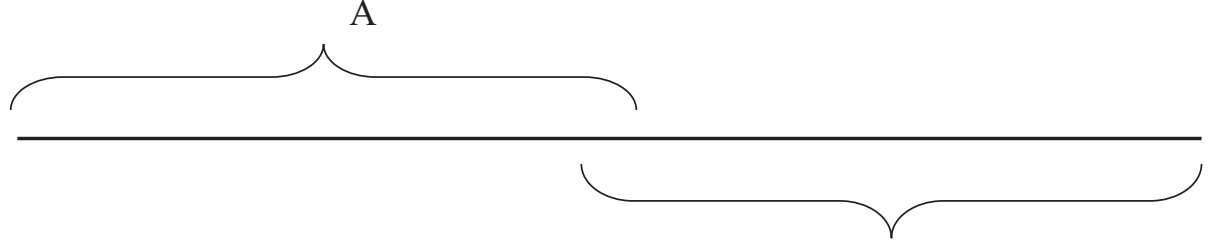

B

A — pracownicy w rozumieniu proceduralnym (art. $476 \S 5$ k.p.c.)

B - osoby wykonujące pracę zarobkową zatrudnione na innej podstawie niż stosunek pracy

Tego rodzaju podział o charakterze podmiotowym rzutuje pośrednio na kognicję sądów w sprawach osób wykonujących pracę zarobkową na innej podstawie niż stosunek pracy. Dyferencjacja podmiotowa zatrudnionych skutkuje zróżnicowaniem kognicji sądów rozpoznających sprawy tych kategorii osób. W efekcie $\mathrm{w}$ ujęciu modelowym $\mathrm{w}$ systemie polskiego prawa procesowego w sprawach zatrudnienia orzekają:

— sądy cywilne (wydziały),

— sądy pracy (wydziały),

— sądy administracyjne.

\section{KOGNICJA SĄDÓW PRACY I SĄDÓW ADMINISTRACYJNYCH}

Centralnym praktycznym zagadnieniem związanym z omawianą problematyką jest kwestia delimitacji kognicji sądów pracy i sądów administracyjnych oraz wydziałów cywilnych i pracy w sprawach osób wykonujących pracę zarobkową na innej podstawie niż stosunek pracy. Ponieważ spór co do kognicji

${ }^{5}$ Ustawa z dnia 23 maja 1991 roku o związkach zawodowych (tekst jedn. Dz.U. z 2019 r. poz. 263 ze zm., dalej: ustawa związkowa). 
sądów w sprawach zatrudnienia osób wykonujących pracę zarobkową na innej podstawie niż stosunek pracy obejmuje przede wszystkim płaszczyzny sądów pracy i sądów administracyjnych, to właśnie ta płaszczyzna zostanie zaprezentowana jako pierwsza. Spór ten dotyczy zarówno zatrudnienia pracowniczego, jak i administracyjnoprawnego. Na marginesie prowadzonych rozważań, których oś zainteresowania stanowi zatrudnienie na innej podstawie niż stosunek pracy, warto pokrótce omówić kwestię sporu co do kognicji sądów pracy i sądów administracyjnych. Norma ustanowiona mocą art. 2 k.p.c. statuuje generalną klauzulę kompetencyjną we wszystkich kategoriach spraw cywilnych, także w indywidualnych sporach pracy. Na tym tle normatywnym powstaje pytanie o korelację kompetencji sądów pracy i sądów administracyjnych. Często niemożliwe jest jednoznaczne rozstrzygnięcie, który sąd jest właściwy w sporze między pracownikiem zatrudnionym w administracji publicznej a podmiotem zatrudniającym. Źródłem tego rodzaju niejasności są zbyt ogólnie sformułowane przepisy regulujące dostęp do drogi sądowej. Szczególne wątpliwości budzi zwłaszcza konstrukcja przyjęta w art. $3 \S 2$ pkt 4 ustawy Prawo o postępowanie przed sądami administracyjnymi ${ }^{6}$, który stanowi, że kontrola działalności administracji publicznej przez sądy administracyjne obejmuje orzekanie w sprawach skarg na akty lub czynności z zakresu administracji publicznej dotyczące uprawnień bądź obowiązków wynikających z przepisów prawa. Wykładnia ekspansywna tego przepisu prowadzi do wniosku, że jego zakres obejmuje również przepisy prawa pracy stosowane przez pracodawców ze sfery administracji publicznej. Naszym zdaniem stosunki pracy w tej sferze mają charakter obligacyjny i dlatego pracodawcy wobec pracowników, co do zasady, nie podejmują czynności z zakresu administracji publicznej ${ }^{7}$ Jednak ze względu na dualistyczny charakter zatrudnienia z mianowania i powołania oraz występowanie w nich pierwiastków władczych o charakterze administracyjnym ${ }^{8}$ tego rodzaju czynności i aktów (z zakresu administracji publicznej) nie można wykluczyć. Stanowią one wówczas immanentną cechę treści stosunku pracy. W tym kontekście uprawniona wydaje się teza, której podstawę stanowi art. 3

${ }^{6}$ Ustawa z dnia 30 sierpnia 2002 roku - Prawo o postępowaniu przed sądami administracyjnymi (tekst jedn. Dz.U. z 2019 r. poz. 2325 ze zm., dalej: p.p.s.a.).

7 Takie stanowisko wyraził na przykład Naczelny Sąd Administracyjny, między innymi w postanowieniu z dnia 27 lutego 2019 roku, I OSK 519/18 (LEX nr 2689863), w którym uznał, że przedstawienia na podstawie art. 165 ust. 7 ustawy z dnia 16 listopada 2016 roku — Przepisy wprowadzające ustawę o Krajowej Administracji Skarbowej (Dz.U. z 2016 r. poz. 1948 ze zm.) propozycji określającej nowe warunki zatrudnienia, nie stanowi aktu lub czynności, o jakich mowa w art. $3 \S 2$ pkt 4 p.p.s.a., bowiem fakt, iż przedstawienie funkcjonariuszowi (w czasie trwającego jeszcze stosunku służbowego) pisemnej propozycji nowych warunków zatrudnienia ma charakter administracyjnoprawny i zindywidualizowany, nie oznacza, aby przedmiotowa propozycja dotyczyła bezpośrednio praw lub obowiązków administracyjnoprawnych i konkretyzowała prawa lub obowiązki administracyjnoprawne wynikające z przepisów prawa.

8 T. Kuczyński, Właściwość sądu administracyjnego w sprawach stosunków służbowych, Wrocław 2000, s. 48-50. 
$\S 3$ p.p.s.a., że podlegają one właściwości sądów administracyjnych. Przepis ten statuuje dyrektywę, zgodnie z którą sądy administracyjne orzekają także w sprawach, w których przepisy ustaw szczególnych przewidują kontrolę sądową i stosują odpowiednie środki.

Istotnym aspektem przy analizie kognicji sądów w sprawach zatrudnienia niepracowniczego jest kwestia delimitacji kompetencji pomiędzy sądami pracy a sądami administracyjnymi na tle sporów powstałych w ramach zatrudnienia administracyjnoprawnego, dotyczących funkcjonariuszy służb mundurowych. $\mathrm{W}$ omawianej materii uprawnione jest stwierdzenie o dominacji kompetencyjnej sądów administracyjnych w kwestiach zatrudnienia funkcjonariuszy. Nieuprawnioną jednak wydaje się w tej kwestii konstatacja o ich monopolu kompetencyjnym. Oto bowiem niektóre pragmatyki przewidują, iż część kategorii spraw związanych z zatrudnieniem administracyjnoprawnym należy do właściwości sądów pracy. Przykładem ilustrującym tego rodzaju sytuację jest choćby art. 220 ustawy o Służbie Więziennej ${ }^{9}$. Przepis ten przekazuje do kompetencji sądów pracy wszystkie spory o roszczenia ze stosunku służbowego funkcjonariuszy Służby Więziennej niewyliczone w art. 218 ust. 1 i 219 ust. 1 i 2 omawianej ustawy ${ }^{10}$. Pierwsza z wymienionych norm, art. 218 ust. 1 ustawy o Służbie Więziennej, obejmuje swoim zakresem cztery kategorie spraw rozstrzyganych w formie decyzji. Należą do nich sprawy dotyczące zwolnienia ze służby, sprawy dotyczące przeniesienia $z$ urzędu do pełnienia służby w innej jednostce organizacyjnej, sprawy dotyczące przeniesienia na niższe stanowisko służbowe oraz sprawy dotyczące zawieszenia w czynnościach służbowych.

Kolejny z przepisów wyłączonych spod kognicji sądów pracy w odniesieniu do funkcjonariuszy służby więziennej mocą art. 220 ustawy o Służbie Więziennej, art. 219 ust. 1 i 2 obejmuje swoją dyspozycją sprawy rozstrzygane w formie rozkazu personalnego. Do katalogu tych spraw ustawodawca zaliczył w pierwszej kolejności sprawy wynikające z podległości służbowej. Należą do nich, zgodnie z art. 219 ust. 1 ustawy o Służbie Więziennej, sprawy dotyczące: powoływania oraz mianowania na stanowiska służbowe, odwoływania oraz zwalniania ze stanowisk służbowych i przenoszenia do dyspozycji, nadawania stopni Służby Więziennej, delegowania do czasowego pełnienia służby w innej jednostce organizacyjnej, oddelegowania do wykonywania zadań służbowych poza Służbą Więzienną w kraju lub poza granicami państwa, oddelegowania do wykonywania

9 Ustawa z dnia 9 kwietnia 2010 roku o Służbie Więziennej (tekst jedn. Dz.U. z 2020 r. poz. 848 ze zm.).

10 Przykładem spraw rozpatrywanych przez sądy pracy są: sprawy dotyczące wydania dokumentów z kasy zapomogowo-pożyczkowej czy rozliczenia stanu konta w tejże kasie (postanowienie NSA z 31 stycznia 2013 roku, I OZ 52/13, LEX nr 1273886); dochodzenie zasądzenia od Skarbu Państwa - właściwego zakładu karnego odpowiedniej kwoty tytułem pomocy finansowej na zaspokojenie potrzeb mieszkaniowych (por. uchwała SN z 13 sierpnia 2013 roku, III PZP 5/13, LEX nr 1360420). 
zadań służbowych w Ministerstwie Sprawiedliwości oraz powierzenia obowiązków służbowych na innym stanowisku służbowym ${ }^{11}$.

Ostatni zakres spraw wyłączonych mocą art. 220 ustawy o Służbie Więziennej spod kognicji sądów pracy, a tym samym poddany kognicji sądownictwa administracyjnego, obejmuje normę z art. 219 ust. 2 ustawy o Służbie Więziennej. Przepis ten dotyczy rozkazu personalnego stwierdzania wygaśnięcia stosunku służbowego.

Omówione wątki czynią uprawnionym stwierdzenie, że w praktyce art. 220 ustawy o Służbie Więziennej ustanawia kognicję sądownictwa pracy ${ }^{12}$ poza obszarami objętymi dyspozycjami norm art. 218 ust. 1 oraz 219 ust. 1 i 2 ustawy o Służbie Więziennej ${ }^{13}$. Mechanizm ten tworzy nową jakość w systemie rozstrzygania sporów funkcjonariuszy zatrudnionych w służbach zmilitaryzowanych. W naszej ocenie w pełni uzasadnione wydaje się kontynuowanie tej tendencji. Co więcej wydaje się, że podlega ona dalszemu rozszerzaniu i obejmuje zupełnie nowe obszary. Mamy tutaj na myśli zwłaszcza kompetencje sądów pracy w zakresie odpowiedzialności dyscyplinarnej. Zgodnie z dyspozycją art. 263 ustawy o Służbie Więziennej od orzeczenia oraz postanowienia kończącego postępowanie dyscyplinarne funkcjonariuszowi przysługuje prawo wniesienia odwołania do właściwego

${ }^{11}$ W tym miejscu należy wskazać, że stosowna regulacja obejmująca sprawy wynikające z podległości służbowej, dotyczące oddelegowania do wykonywania zadań służbowych w Ministerstwie Sprawiedliwości rozstrzygane w formie rozkazu personalnego (art. 219 ust. 1 pkt 5a ustawy o Służbie Więziennej), została wprowadzona mocą ustawy z dnia 22 marca 2018 roku o zmianie ustawy o Służbie Więziennej oraz niektórych innych ustaw (Dz.U. z 2018 r. poz. 912). Norma ta dotyczy wyłącznie rozkazu personalnego oddelegowania do wykonywania zadań służbowych w Ministerstwie Sprawiedliwości, nie zaś wykonywania tam określonych zadań. Zgodnie z uzasadnieniem do projektu wspomnianej ustawy uregulowana ustawowo możliwość oddelegowania funkcjonariuszy do pełnienia służby w Ministerstwie Sprawiedliwości spowoduje, że ich ewentualne czynności wobec jednostek organizacyjnych Służby Więziennej nie będą nacechowane względami podległości służbowej (druk nr 2155 Sejmu VIII kadencji, Rządowy projekt ustawy o zmianie ustawy o Służbie Więziennej oraz niektórych innych ustaw, s. 42). Tym samym spod kognicji sądów pracy (a contrario do normy art. $220 \mathrm{w}$ zw. z art. 219 ust. 1 pkt 5a ustawy o Służbie Więziennej) wyłączono sam rozkaz personalny dotyczący oddelegowania do wykonywania zadań służbowych w Ministerstwie Sprawiedliwości, nie zaś sprawy dotyczące czynności podejmowanych w czasie takiego oddelegowania. Czynności takie podlegają zatem, zgodnie z art. 220 ustawy o Służbie Więziennej, kognicji sądów pracy.

12 Jak wskazał Wojewódzki Sąd Administracyjny w Poznaniu w wyroku z 25 kwietnia 2012 roku II SA/Po 1242/11, LEX nr 1258910), przepis art. 220 ustawy z 2010 roku o Służbie Więziennej w sposób niebudzący wątpliwości wskazuje kognicję sądu pracy w zakresie roszczeń nieprzekazanych na drogę innych postępowań. Takie odesłanie wyklucza możliwość stosowania domniemań co do właściwości sądu powszechnego lub sądu administracyjnego w sprawach ze stosunków służbowych funkcjonariuszy Służby Więziennej. Kwestie te zostały uregulowane explicite.

13 Por. B. Baran, Dualizm dróg sadowych w sprawach ze stosunku stużbowego funkcjonariuszy stużby więziennej, „Roczniki Administracji i Prawa” 19, 2019, nr 1, s. 276-277; T. Kuczyński, Wybrane problemy orzecznictwa sq̨dowoadministracyjnego $w$ sprawach z zakresu stosunków sluzbowych, „Zeszyty Naukowe Sądownictwa Administracyjnego” 2010, nr 5-6, s. 257. 
ze względu na miejsce zamieszkania obwinionego sądu pracy, w terminie 14 dni od dnia doręczenia orzeczenia lub postanowienia wraz z uzasadnieniem ${ }^{14}$.

Powyższe rozwiązanie wyróżnia ustawę o Służbie Więziennej na tle innych pragmatyk służb mundurowych, które w analogicznych sytuacjach przewidują drogę postępowania sądowoadministracyjnego ${ }^{15}$. Mowa tutaj na przykład o art. 138 ustawy o Policji ${ }^{16}$, zgodnie z którym od orzeczenia i postanowienia kończących postępowanie dyscyplinarne policjantowi przysługuje prawo wniesienia skargi do sądu administracyjnego.

Właściwość sądu pracy częstokroć wynika z konkretnego odesłania ustawowego bądź braku regulacji przeciwnej, wyłączającej jego kompetencję. Przykładem tak unormowanej kompetencji sądów pracy są sprawy związane z zatrudnianiem sędziów jako przedstawicieli władzy sądowniczej i prokuratorów. Ukształtowanie kompetencji sądów pracy względem tych dwóch grup podmiotów nie jest jednakowe. Wypada $\mathrm{w}$ tym miejscu nadmienić, że kontrola działalności administracji publicznej sprawowana, zgodnie z art. 184 Konstytucji RP, przez Naczelny Sąd Administracyjny i inne sądy administracyjne nie obejmuje spraw związanych z zatrudnianiem sędziów i prokuratorów.

Kompetencja sądu pracy do rozstrzygania sporów służbowych dotyczących sędziów opiera się na wykładni art. $89 \S 2$ ustawy Prawo o ustroju sądów powszechnych ${ }^{17}$. Zgodnie z przywołaną normą sędziom w sprawach o roszczenia ze stosunku służbowego przysługuje droga sądowa. Na podstawie ogólnej dyrektywy delimitacyjnej sąd administracyjny w sprawach zatrudnienia orzeka tylko wtedy, gdy jego właściwość została explicite wskazana szczególnym przepisem ustawy. Przepis art. $89 \S 2$ p.u.s.p. takiego odesłania nie zawiera. Bezsporne jest zatem, że rozpoznanie spraw o roszczenia ze stosunku służbowego sędziów sądów powszechnych, również w odniesieniu do sędziów w stanie spoczynku ${ }^{18}, \mathrm{z}$ braku odrębnej regulacji, odbywa się przed sądami pracy.

Sprawy z zakresu prawa pracy dotyczące sędziów Sądu Najwyższego, zgodnie z art. 27 § 1 pkt 2 ustawy z dnia 8 grudnia 2017 roku o Sądzie Najwyższym ${ }^{19}$, przyznane zostały kompetencji Izby Dyscyplinarnej Sądu Najwyższego ${ }^{20}$. Postę-

14 Problematykę tę szczegółowo omówiła B. Baran, Postępowanie dyscyplinarne w sprawach funkcjonariuszy Stużby Więziennej, Warszawa 2016, passim.

15 F. Radoniewicz, [w:] Stużba więzienna. Komentarz, red. M. Mazuryk, M. Zoń, Warszawa 2013, LEX, art. 263.

16 Ustawa z dnia 6 kwietnia 1990 roku o Policji (tekst jedn. Dz.U. z 2020 r. poz. 360 ze zm.).

17 Ustawa z dnia 27 lipca 2001 roku - Prawo o ustroju sądów powszechnych (tekst jedn. Dz.U. z 2020 r. poz. 2072, dalej: p.u.s.p.).

18 W wyroku z dnia 6 stycznia 1999 roku, III RN 180/98, OSNAPiUS 1999, nr 21, poz. 670, Sąd Najwyższy stanął na stanowisku, że także sędzia w stanie spoczynku może dochodzić przed sądem pracy roszczeń wynikających ze stosunku służbowego.

19 Tekst jedn. Dz.U. z 2021 r. poz. 154.

${ }^{20}$ Należy zauważyć, że Izba Dyscyplinarna Sądu Najwyższego nie jest sądem w rozumieniu art. 175 ust. 1 Konstytucji RP. 
powanie w sprawach z zakresu prawa pracy dotyczące sędziów Sądu Najwyższego jest dwuinstancyjne. W pierwszej instancji orzeka Sąd Najwyższy złożony z jednego sędziego Izby Dyscyplinarnej, w drugiej zaś - Sąd Najwyższy w składzie trzech sędziów Izby Dyscyplinarnej. Powyższa regulacja, wprowadzona mocą art. 79 ustawy o Sądzie Najwyższym, ma zastosowanie również do sędziów oddelegowanych do pełnienia czynności sędziowskich w Sądzie Najwyższym. Zgodnie z art. 40 ust. 2 ustawy o Sądzie Najwyższym w okresie delegowania do pełnienia czynności sędziowskich w Sądzie Najwyższym do delegowanego sędziego mają odpowiednio zastosowanie przepisy określające prawa i obowiązki sędziego Sądu Najwyższego. Normy wyznaczające kognicję Izby Dyscyplinarnej Sądu Najwyższego w zakresie spraw z zakresu prawa pracy mieszczą się w dyspozycji pojęcia „praw i obowiązków sędziego Sądu Najwyższego”. Zgodnie z terminologią przyjętą w art. $476 \S 1$ k.p.c. do „spraw z zakresu prawa pracy” należą sprawy związane $\mathrm{z}$ egzekwowaniem określonych praw. Toteż argumentując a coherentia, w zakres przedmiotowy objęcia sędziów delegowanych do Sądu Najwyższego w dotyczących ich sprawach z zakresu prawa pracy wchodzi kognicja Izby Dyscyplinarnej.

Brak podstaw do funkcjonowania Izby Dyscyplinarnej Sądu Najwyższego w aktualnym stanie prawnym nie budzi wątpliwości. Racjonalność takiego poglądu potwierdzona została uchwałą składu połączonych izb: Cywilnej, Karnej oraz Pracy i Ubezpieczeń Społecznych Sądu Najwyższego ${ }^{21}$. Stanowi ona o nienależytym obsadzeniu Izby Dyscyplinarnej Sądu Najwyższego, przez wejście w jej skład osoby powołanej na urząd sędziego Sądu Najwyższego na wniosek Krajowej Rady Sądownictwa ukształtowanej w trybie określonym przepisami ustawy z 2017 roku o zmianie ustawy o Krajowej Radzie Sądownictwa oraz niektórych innych ustaw. Uchwała ta uznana została za niekonstytucyjną wyrokiem Trybunału Konstytucyjnego z dnia 20 kwietnia 2020 roku$^{22}$. Istotność tego orzeczenia traci jednak na znaczeniu wobec wyroku Trybunału Sprawiedliwości Unii Europejskiej z dnia 15 lipca 2021 roku $^{23}$, zgodnie z którym Rzeczpospolita Polska uchybiła zobowiązaniom, które na niej ciążą na mocy art. 19 ust. 1 akapit drugi Traktatu o Unii Europejskiej. Uchybienia te wynikają, między innymi, z niezapewnienia niezależności i bezstronności Izby Dyscyplinarnej Sądu Najwyższego. Wobec powyższego, ze względu na funkcjonowanie Izby Dyscyplinarnej z naruszeniem przepisów prawa unijnego oraz krajowego, jednoznacznie stwierdzić należy, że w obecnym stanie prawnym nie istnieje droga sądowa w odniesieniu do spraw z zakresu prawa pracy dochodzonych przez sędziów Sądu Najwyższego oraz sędziów do niego delegowanych, co rażąco narusza standardy konstytucyjne.

W wypadku prokuratorów kognicji sądów pracy explicite poddane zostały spory dotyczące stosunku służbowego, który na podstawie mianowania nawią-

21 Uchwała SN z 23 stycznia 2020 roku, BSA I-4110-1/20, LEX nr 2770251.

22 Wyrok TK z 20 kwietnia 2020 roku, U 2/20, OTK-A 2020, nr 61.

23 Wyrok TSUE z 15 lipca 2021 roku, C-791/19, ECLI:EU:C:2020:147. 
zany jest $\mathrm{z}$ chwilą doręczenia zawiadomienia o powołaniu. Poddanie sporów o roszczenia ze stosunku służbowego prokuratorów kognicji sądów pracy wynika $\mathrm{z}$ art. $101 \S 1$ ustawy Prawo o prokuraturze ${ }^{24}$. Bezsporne jest zatem, że sprawy z zakresu prawa pracy, inne niż ze stosunku pracy, wchodzą w odniesieniu do prokuratorów do obszaru kompetencyjnego sądów pracy, ponieważ żaden inny przepis, nawet implicite, nie wskazuje innego trybu dochodzenia roszczeń ${ }^{25}$. Analogicznie kształtuje się kompetencja sądów pracy w zakresie spraw dotyczących asesorów zatrudnionych w powszechnych jednostkach organizacyjnych prokuratury, do których mocą art. 174 ust. 1 pkt 1 u.p. zastosowanie znajdują odpowiednio przepisy dotyczące prokuratorów z pewnymi włączeniami, w których zakres nie wchodzi art. 101 u.p.

\section{KOGNICJA WYDZIAŁÓW CYWILNYCH I WYDZIAŁÓW PRACY}

Poza koniecznością ustalenia kognicji między sądami pracy a sądami administracyjnymi istotną kwestią jest również dokonanie rozróżnienia sfery kompetencyjnej, a pośrednio i proceduralnej, między sądami pracy a sądami cywilnymi. W wypadku osób zatrudnionych na podstawie umów zlecenia, umów o świadczenie usług, a nawet o dzieło na podstawie kryteriów przedmiotowych przewidzianych w art. $476 \S 1$ pkt 2 k.p.c. i art. $262 \S 1$ k.p., uprawnione a contario jawi się stwierdzenie, że roszczenia z tego rodzaju stosunków prawnych należą do kompetencji wydziałów (sądów) cywilnych, chyba że przepisy statuują specjalne odesłanie do norm prawa pracy. W swej istocie podobna reguła rządzi roszczeniami członków rolniczych spółdzielni produkcyjnych. Zgodnie z utrwalonym od lat orzecznictwem sprawy o wypłatę wynagrodzenia ${ }^{26}$, o odszkodowanie $\mathrm{z}$ tytułu pozbawienia pracy $\mathrm{w}$ rolniczej spółdzielni produkcyjnej ${ }^{27}$ oraz o zapłatę premii i ekwiwalentu za urlop wypoczynkowy nie mieszczą się w zakresie kognicji sądownictwa pracy ${ }^{28}$.

W tym kontekście, co do zasady, właściwa wydaje się konstatacja, że sprawy o roszczenia wynikające ze świadczenia pracy na podstawie umów cywilnoprawnych leżą w gestii wydziałów cywilnych. De lege lata w tej materii występują jednak wyjątki. Przykładem jest regulacja z art. 3 ust. 3 ustawy o związkach zawodowych, która explicite przekazuje sprawy na tle nierównego traktowania w zatrudnieniu z powodu przynależności do związku zawodowego lub pozostawania

${ }^{24}$ Ustawa z dnia 28 stycznia 2016 roku — Prawo o prokuraturze (tekst jedn. Dz.U. z 2021 r. poz. 66, dalej: u.p.).

25 E. Baran, K.W. Baran, Droga sądowa z zakresu prawa pracy osób zatrudnionych w powszechnych jednostkach organizacyjnych prokuratury, „Prokuratura i Prawo” 1995/1996, s. 69.

26 Por. uchwałę SN z dnia 25 lipca 1986 roku, III PZP 43/86, PiZS 1986, nr 12, s. 74.

27 Por. uchwałę SN z dnia 15 sierpnia 1986 roku, III PZP 52/86, OSNC 1987, nr 7, poz. 99.

28 Por. uchwałę SN z dnia 15 sierpnia 1986 II PZP 51/86, OSNC 1987, nr 7, poz. 98. 
poza nim albo wykonywania funkcji związkowej osób wykonujących prace zarobkową - lege non distinguente, także nie pracowników, do właściwości sądów pracy. W naszej ocenie tego rodzaju sprawy powinny być kwalifikowane na gruncie prawa procesowego jako sprawy o roszczenia $\mathrm{z}$ innych stosunków prawnych, do których z mocy odrębnych przepisów stosuje się przepisy prawa pracy (art. 476 $\S 1$ pkt 2 k.p.c.). Ustawa związkowa explicite wskazuje bowiem na kognicję sądu pracy. Do kategorii podmiotów niebędących pracownikami, objętych regulacją art. 3 ust. 3 ustawy związkowej należy zaliczyć (na podstawie art. 3 ust. 1 ustawy związkowej w związku z art. 2 ust. 1 i 3-6 ustawy związkowej):

- osoby wykonujące pracę zarobkową, to jest zgodnie $\mathrm{z}$ art. $1^{1}$ pkt 1 ustawy związkowej osoby świadczące pracę za wynagrodzeniem na innej podstawie niż stosunek pracy, jeżeli nie zatrudniają do tego rodzaju pracy innych osób, niezależnie od podstawy zatrudnienia, oraz mają takie prawa i interesy związane z wykonywaniem pracy, które mogą być reprezentowane i bronione przez związek zawodowy również po ich przejściu na emeryturę (art. 2 ust. 1 i 3 ustawy związkowej);

- osoby bezrobotne w rozumieniu przepisów o zatrudnieniu (art. 2 ust. 4 ustawy związkowej);

- wolontariuszy, stażystów i inne osoby, które świadczą osobiście pracę bez wynagrodzenia, (art. 2 ust. $4^{1}$ ustawy związkowej);

- osoby skierowane do pracodawców w celu odbycia służby zastępczej (art. 2 ust. 5 ustawy związkowej);

— funkcjonariuszy Policji, Straży Granicznej, Służby Celno-Skarbowej i Służby Więziennej oraz strażaków Państwowej Straży Pożarnej, a także pracowników Najwyższej Izby Kontroli (art. 2 ust. 6 ustawy związkowej z uwzględnieniem ograniczeń wynikających z odrębnych ustaw).

Poważniejsze problemy ujawniają się, gdy przepisy ustawodawstwa pracy takiego odesłania verba legis nie statuują. Można tu wskazać, w odniesieniu do osób świadczących pracę na podstawach cywilnoprawnych będących działaczami związkowymi, spory dotyczące uprawnień:

— do zwolnień od pracy z art. 31 ustawy związkowej,

- w zakresie ochrony trwałości stosunku zatrudnienia z art. 32 (szczebel zakładowy) i art. $34^{2}$ (międzyzakładowy, ponadzakładowy) tej ustawy. Obowiązujące regulacje nie precyzują właściwości sądu w tej materii, co w praktyce generuje wątpliwości interpretacyjne. W naszym przekonaniu można jednak kategorie sporów zaistniałych na tym tle przypisać do spraw z art. $476 \S 1$ pkt 2 k.p.c. Przepisy art. 31, 32 i $34^{2}$ ustawy związkowej mają niewątpliwie przymiot norm prawa pracy, a w wymiarze podmiotowym odnoszą się też do innych niż pracownicy osób wykonujących pracę zarobkową, co wprost wynika z ich treści. W efekcie uzasadnionym jawi się stwierdzenie, że należą do kognicji sądów pracy. Za tego rodzaju opcją interpretacyjną przemawiają także względy funkcjonalne. Przeciwna interpretacja oznaczałaby zróżnicowaną kognicję w zależności od tego, czy roszczenia dochodziłby pracownik, czy też osoba wykonująca pracę zarobkową niebędąca 
pracownikiem. Spory sądowe, których podstawą materialną będą art. 31, 32 i $34^{2}$ ustawy związkowej wydają się możliwe do zakwalifikowania jako kategoria postępowań w sprawach dotyczących wykonywania funkcji związkowej, o których mowa w art. 3 ust. 3 tej ustawy, co czyniłoby je możliwymi do zakwalifikowania jako sprawy podlegające kognicji sądów pracy.

\section{PODSUMOWANIE}

Przedstawione uwagi zarysowują panoramę zagadnień związanych z kognicją sądów pracy w sprawach zatrudnienia osób wykonujących pracę zarobkową na innej podstawie niż stosunek pracy. Reasumując je, konkludujemy, że w zakresie rozstrzygania spraw osób świadczących pracę na innej podstawie niż stosunek pracy występuje zjawisko rozproszenia kompetencji sądów. Generuje to wiele negatywnych następstw (na przykład negatywne spory kompetencyjne).

De lege ferenda, nieco utopijnie, postulujemy skupienie orzecznictwa w sprawach zatrudnienia niepracowniczego w kognicji sądownictwa pracy jako wyspecjalizowanej w tej materii struktury sądowej. Spełnienie postulowanego założenia z pewnością przyczyniłoby się do pełniejszej realizacji prawa do sądu. Gwarantowałoby bowiem wykluczenie wątpliwości co do kognicji sądów w sprawach dotyczących zatrudnienia osób wykonujących pracę zarobkową na innej podstawie niż stosunek pracy.

\section{COGNIZANCE OF COURTS IN MATTERS OF EMPLOYMENT OF PERSONS PERFORMING GAINFUL EMPLOYMENT ON A BASIS OTHER THAN THE EMPLOYMENT RELATIONSHIP}

\section{Summary}

In order to be able to fully and consciously exercise the right to a court, the person who wants to fully benefit from it should be clear about the path to court. Among fundamental manifestations of the right to a court is the cognizance of the court. The current legal state leaves numerous doubts as to the scope of the cognizance of the court in cases of employment of persons performing for-profit employment on a basis other than the employment relationship. The above is particularly evident in the scope of providing work on the basis of contracts regulated in the civil code and in the scope of administrative employment. The systemic inconsistency creates doubt as to the full implementation of the right to a court guaranteed by the Polish system, requiring the definition of the scope of the court cognizance at the indicated levels.

Keywords: cognizance of courts, employment cases, persons performing gainful employment, non-workers 


\section{BIBLIOGRAFIA}

Baran B., Dualizm dróg sądowych w sprawach ze stosunku stużbowego funkcjonariuszy stużby więziennej, „Roczniki Administracji i Prawa” 19, 2019, nr 1.

Baran K., Książek D., Wujczyk M., Procesowe prawo pracy, Warszawa 2013.

Konstytucja Rzeczypospolitej Polskiej z dnia 2 kwietnia 1997 roku, Dz.U. z 1997 r. Nr 78, poz. 483 ze zm.

Konwencja o ochronie praw człowieka i podstawowych wolności sporządzona w Rzymie dnia 4 listopada 1950 roku, Dz.U. z 1993 r. Nr 1, poz. 281.

Kuczyński T., Właściwość sądu administracyjnego w sprawach stosunków stużbowych, Wrocław 2000.

Kuczyński T., Wybrane problemy orzecznictwa sadowoadministracyjnego $w$ sprawach $z$ zakresu stosunków stużbowych, „Zeszyty Naukowe Sądownictwa Administracyjnego” 2010, nr 5-6.

Międzynarodowy Pakt Praw Obywatelskich i Politycznych otwarty do podpisu w Nowym Jorku dnia 19 grudnia 1966 roku, Dz.U. z 1977 r. Nr 38, poz. 167.

Postanowienie Naczelnego Sądu Administracyjnego z 31 stycznia 2013 roku, I OZ 52/13, LEX nr 1273886.

Postanowieniu Naczelnego Sądu Administracyjnego z dnia 27 lutego 2019 roku, I OSK 519/18, LEX nr 2689863.

Radoniewicz F., [w:] Stużba więzienna. Komentarz, red. M. Mazuryk, M. Zoń, Warszawa 2013, LEX.

Rządowy projekt ustawy o zmianie ustawy o Służbie Więziennej oraz niektórych innych ustaw, druk nr 2155 Sejmu VIII kadencji.

Uchwała Sądu Najwyższego z dnia 13 sierpnia 2013 roku, III PZP 5/13, LEX nr 1360420.

Uchwała Sądu Najwyższego z dnia 15 sierpnia 1986 roku, II PZP 51/86, OSNC 1987, nr 7, poz. 98.

Uchwała Sądu Najwyższego z dnia 15 sierpnia 1986 roku, III PZP 52/86, OSNC 1987, nr 7, poz. 99.

Uchwała Sądu Najwyższego z dnia 25 lipca 1986 roku, III PZP 43/86, PiZS 1986, nr 12.

Uchwała Sądu Najwyższego z dnia 23 stycznia 2020 roku, BSA I-4110-1/20, LEX nr 2770251.

Ustawa z dnia 16 listopada 2016 roku - Przepisy wprowadzające ustawę o Krajowej Administracji Skarbowej, Dz.U. z 2016 r. poz. 1948 ze zm.

Ustawa z dnia 17 listopada 1964 roku — Kodeks postępowania cywilnego, tekst jedn. Dz.U. z 2020 r. poz. 1575 ze zm.

Ustawa z dnia 22 marca 2018 roku o zmianie ustawy o Służbie Więziennej oraz niektórych innych ustaw, Dz.U. z 2018 r. poz. 912.

Ustawa z dnia 23 maja 1991 roku o związkach zawodowych, tekst jedn. Dz.U. z 2019 r. poz. 263 ze zm.

Ustawa z dnia 27 lipca 2001 roku - Prawo o ustroju sądów powszechnych, tekst jedn. Dz.U. z 2020 r. poz. 2072.

Ustawa z dnia 28 stycznia 2016 roku - Prawo o prokuraturze, tekst jedn. Dz.U. z 2021 r. poz. 66.

Ustawa z dnia 30 sierpnia 2002 roku - Prawo o postępowaniu przed sądami administracyjnymi, tekst jedn. Dz.U. z 2019 r. poz. 2325 ze zm.

Ustawa z dnia 6 kwietnia 1990 roku o Policji, tekst jedn. Dz.U. z 2020 r. poz. 360 ze zm.

Ustawa z dnia 8 grudnia 2017 roku o Sądzie Najwyższym, tekst jedn. Dz.U. z 2021 r. poz. 154.

Ustawa z dnia 9 kwietnia 2010 roku o Służbie Więziennej, tekst jedn. Dz.U. z 2020 r. poz. 848 ze zm. Wyrok Trybunału Konstytucyjnego z dnia 20 kwietnia 2020 roku, U 2/20, OTK-A 2020, nr 61.

Wyrok Trybunału Sprawiedliwości Unii Europejskiej z dnia 15 lipca 2021 roku, C-791/19, ECLI: EU:C:2020:147

Wyrok Wojewódzkiego Sądu Administracyjnego w Poznaniu z 25 kwietnia 2012 roku, II SA/Po 1242/11, LEX nr 1258910. 